\title{
The Kalesang Values Contribution To The Students' \\ Success In The Faculty of Theology of Indonesian Christian University in the Moluccas (UKIM) Ambon.
}

\author{
ClaartjePattinama \\ Sekolah Tinggi Teologi Ambon \\ Email; claartje@gmail.com
}

\begin{abstract}
The successful student of the Faculty of Theology in completing his or her study for becoming a priest as his or her goal is determined by several factors, such as: cultures, Ambonese family traditions, motivations and commitments.Cultures and family traditions influence the success in completing his or her study to achieve his or her goal for becoming a priest. A student who has hereditary priest in his or her family will be encouraged strongly by the family to become a priest. To Ambonese people, becoming a priest is considered to be a prestige. Not only the priest but also his or her whole family are proud of becoming priests, even though they only receive lower salary compared to the salary of a state officer. They will not mind to receive lower salary as a priest in the world because they believe that they will have a big salary in heaven. The kind of belief is rooted in the culture or Ambonese belief that glorying God has to be the first priority in everything they do. The second priority is respecting their parents or their ancestors who want their next generations to follow their steps for working and serving God as priests.
\end{abstract}




\section{Introduction}

The traditions and cultures stated above affect and support students of the Faculty of Theology. The students' will to become priests are supported by their parents and their whole family. The students are glad because their parents and their whole family take care of their study to become priests. The culture of "kalesang" (caring) from the whole family becomes a great support for the success of their study to become priests. It also has the connection with having the good reputation of their family, who worked as priests of The Protestant Church in the Moluccas or outside the Moluccas and who passed down their belief and hopes for becoming priests.

The awareness of serving as a priest starts from the opening of School Toot Opleiding Van Inlands Leraren (STOVIL) ON April 11, 1885 in Ambon. The education of STOVIL was very strict because every student had to obey the prevailing rules. The students were not allowed to drink alcohol, smoke, have black magic and cast spells. The education expected the students to really believe in God and behave well. They were expected to be good examples for the society and congregations before becoming priests. Becoming priests mean becoming spiritual leaders and good examples for church members and society. Becoming priests is valued based on their consistency of their words and deeds. Words here means in spreading the Words of God or preaching and giving advice to the church members in accordance with their behavior or deeds. Therefore, as students before becoming priests are considered hard that need strong supports from their parents and their whole family.

Besides having self motivation and good behavior during their study, the students have to show their commitments to study, obey the rules in order to complete their study and achieve their goals to become priests. Motivation reflects their inner force to work or complete tasks (Schunk, 2008). The commitment here means the loyalty to their own promise to 
become the servant of the congregations. Besides promising themselves, having commitment also means promising to surrender themselves to God (Hunter 1990) by studying hard to serve in His Work as priests. The students' commitment may be seen in their loyalty to study hard and obey all the prevailing rules in the Faculty of Theology.

The students' motivation and commitment to complete their study and become priests may not be achieved if their family do not apply the "kalesang" culturetowards their aspirations. In other words, the factor of culture really affects a person to complete his or her study and achieve his or her goal to become a priest.

Everyone who wants to become a priest may study atevery Theological school wherever it is. In Ambon, a lot of students who want to become priests of The Protestant Church in the Moluccas (GPM) prefer to study at the Faculty of Theology of Indonesian Christian University in the Moluccas (UKIM). Historically, UKIM was the development of Theological School of GPM (STT-GPM). The establishment of UKIM was started from STT-GPM. Since the existence of UKIM in 1985, the Faculty of Theology has been considered then to be the eldest Faculty of UKIM. There are five Faculties of UKIM, they are: The Faculty of Theology, The Faculty of Political and Social Science, The Faculty of Economics, The Faculty of Civil Engineering, and the Faculty of Health.

Students are getting more interested in the Faculty of Theology of UKIM. It's because of their interest in becoming a priest of GPM. Based on their family history, they are hereditary from their parents or relatives who become priests.

To Moluccan Christian people, becoming a priest is considered to be noble and as God's servant who spread the Word of God to a lot of people, to do ministry and hold Christian Education. Also, a priest is a person who is expected to create good relations with other people from other religions. 
The success of a theological student to become a priest is determined by the support of the family culture, motivations and a strong commitment of a student who wants to become a priest. The family "kalesang" culture is in accordance with the safe life in the world and the hereafte.

\section{The Role of the Theological Faculty in Guiding the Students}

UKIM Theological Faculty has an important role in educating and preparing every student to complete his or her study. During his or her study at UKIM Theological Faculty, a student has to be put into consideration not only intellectually but also morally and spiritually to be prepared for his or her success in studying. The reason is that because the student who is educated atUKIM Theological Faculty will finally become a priest who will play an important functional role as a spiritual leader to his or her congregations or church communities served (Hall, 1992).

The basic principle of theological education is centered on The Word of God, rooted in the church, and oriented on the world. UKIM Theological Faculty is trying to manifest the responsibility for preparing the students as prospective priests by applying the educational system focused on academic formation, spiritual formation and practical formation (Spiritual Formation in Asian Theological Education, 1989).It is in accordance then with the statement that the main function of theological education consists of three things, they are: academic development, spiritual maturity, and doing the ministry (Association for Theological Education in South East Asia Handbook, 2000).

The educational system and formation above is integrated in the whole curriculum of the Faculty by also having extra curricular activities. The goals of the educational system applied will produce the competent outputs who have: 
1. Knowledge and understanding about theology and its branches, including understanding other religions in Indonesia.

2. Intellectual skills by applying the theory and methods in theology.

3. Practical skills in order to analyze the problems of church, society, nation in various aspects (social, politics, economy, law, etc.), and be able to do pastoral ministry to individuals and groups of society, also, be able to educate church members and society responsibly.

4. Managerial skills by being able to communicate actively, organize the congregations and society to do ministry and empowerment, and coordinate and cooperate with every components of the church and society. Also, adoring spirituality, norms, moral values and professional responsibility (Dean of UKIM Theological Faculty, 2008).

The competence above is based on the vision and mission of the Theological Faculty. One of the mission is that preparing, educating and forming theological scholars who are able to serve the church and society in the fields of pastoral, education and empowerment. Based on the competence of the outputs, the teaching-learning process not only emphasizing the academic knowledge but also forming attitude and character building of the prospective priests expected and forming the spiritual values of life, like: truth, justice, trust, understanding, tolerance, responsibility, honesty, love, goodness, and other positive values of moral ethics (Buzan, 2001). Therefore, religious values are important in the teaching-learning process of the Theological Faculty. They are shown in the core of every subject, the campus services, and teacher-student tutorial meetings.

Every teacher has a responsibility for motivating students to complete their study well. Theteachers are aware of the students' achievement and behavior. Historically, it started from the theological education of School Tot 
OpleidingVoorInlansch-Leeraar (STOVIL) in 1885 (Duyyerman, 1972). The students of STOVIL were strictly educated. They were not allowed to smoke, drink alcohol, and have black magic. The reason of having the strict regulations was that they were going to become prospective spiritual leaders to their congregations. Therefore, they had to be good examples for their followers. The students of STOVIL were from Ambonese or Moluccan people. They were prepared for becoming congregation leaders so that they could understand their indigenous language and ministry in their context better. It's different from the Netherlands priests who did not understand the indigenous language in Amboneseand Moluccan contexts.

Now days, the Theological students are not allowed to drink alcohol. They should have moral ethics as prospective servants of congregations expected. Otherwise, they might be disciplined of even kicked out. Since their entrance of the Theological Faculty, every student should know and obey the prevailing academic and student regulations at the Faculty of Theology.

The Faculty is responsible for the progress of the students and report it to their parents or relative in charge of them. If students do not behave well or do not obey the regulations morally and ethically, their parents or relative in charge of them will have to see or consult with the Dean or the staff members of the Faculty.

\section{Students' Motivation to Become Priests.}

According to Schunk, et al., (2008), motivation is derived from the Latin word movere(to move), that shows a person's inner support to do something and complete tasks. Motivation is described in various ways, including the self inner power, the continuous characteristics, stimulus response, form influence and trust. Motivation is also associated with the will. 
The students' motivation to study at the Faculty of Theology are becoming priests who serve GPM congregations. It's in accordance with the motivation defined by Schunk, et.al. (2008), that motivation is a process to support and strengthen activities for achieving goals. Therefore, the will to be educated need teaching-learning process that support the students' will to strengthen learning activitiesfor achieving their goal of becoming priests.

Schunk, et.al. (2008) describes that motivation needs physical and mental activities. Physical activities cover the real effort or perseverance or other actions needed. Mental activities cover cognitive activities like: planning, organizing, solving problems, making decisions, and valuing the progress made. Thus, most of the students' activities in studying is connected with the ability to achieve their goal of becoming priests.

Motivation involves goals, in this case, their main goal of becoming a priest. To achieve their goals they need five to seven years of studying. Becoming a priest is considered to be a long term goal. After finishing studying, they have to put into practice by having avicar period for two years done by the Staff members of GPM Synod Board. The students have to plan their study well by passing all the semester subjects that strengthen their motivation and self confidence to achieve their long term goal of becoming a priest.

According to Cote and Levine (1997), there are five students' motivations to enter Higher Education, they are:

1. Career-material motivation, that is, the students' motivation to see the Higher Education as a way to achieve career, social status, success and everything that please to life.

2. Personal intellectual development, that is, the students' motivation emphasizing on personal development by learning to understand their complicated life. 
3. Human motivation, that is, the students' motivation by caring for unfortunate people and wanting to change the system to improve human life and the world.

4. Expectations and supports from their parents and family, that is, the students' motivation by giving response to the expectations of their parents and family to achieve a degree.

5. No other choice, that is, the students have no clear motivation to enter Higher Education. In other words, they do not know why and what for to enter Higher Education.

Based on the five motivations of Cote and Levine above, there are only three of them that suit the motivations of UKIM Theological Faculty Ambon, they are, the intellectual development motivation, human motivation, expectations and supports from their parents or family. The three motivations suit the students' aspirations to become priests and serve GPM congregations who face complicated problems.

To Ambonese and the Moluccan society, a priest may bring goodness to a lot of people. The position as a priest is assumed to be the position of trust given by God to save people from their problems of life. Therefore, a priest has to care for others' life which is shown in his or her ministry that touches a lot of people's needs.

Moreover, Schunk, et.al. (2008) states, by citing from Bandura, Locke and Leatham, that setting goals is a key of a motivation process. By studying hard the students have strong motivations to achieve their goals to become priests. They also need supports from their parents or the whole family who really 'kalesang'or care for them to achieve their goals to become priests of the next generation.In other words, the kalesang culture of their parents or family strengthens the students' motivation to carry on becoming priests of the next generation.

GPM Synod board will ordain a priest who has passed the examination of a vicar period. However, becoming a priest 
is determined by not only his or her intelligence but also his or her attitude and ministerial quality in faith and life as a spiritual leader who becomes a good example to his or her church members.

His or her faith quality as a priest is important to the family that brings a good name to the whole family. The family kalesang culture is really manifested to keep on caring for the students to carry on their responsibility for their whole family nobleness.

\section{The Students' Commitment to Their Aspirations}

To become a priest a student has to have not only a motivation but also a strong commitment to his or her aspirations. Being committed himself or herself to study hard in order to become a priest is really needed by completing the tasks of studying based on the prevailing norms at the Theological Faculty.

It's also stated by Marcia and Archer in connection with adolescence development from the age of 18 to 22 (Marcia and Archer, 1993), that this age, a person performs cognitive and behavioral choices, like: religions, fields of study, jobs, future wife or husband, etc. The decision made by a person is determined by the way he or she explores the choices that has a connection with his or her identity. If he or she makes a choice to study at the Theological Faculty to become a priest, it becomes his of her strong commitment to achieve his or her aspiration.

Hunter (1990) says that commitment is a self giving or self connection to something for reaching goals of life. The theological basic concept dealing with commitment is covenant which is shown in a theme of calling for vocation. It has the connection with the students' decision to study at the Theological Faculty with their goal to become a priest. The students tend to say that "they are called" while being

JICSA Volume 05- Number 01, June 2016 


\section{ClaartjePattinama}

interviewed at the Theological Faculty. Their expression of being called becomes their self giving to be tied up in the process of being educated in academic, spiritual and practical formation for becoming a priest. So, their commitment to become a priest is their commitment to be manifested ethically and morally in their study well. In other words, their self givingability has a connection with making themself getting used to the prevailing norms and regulations at the Theological Faculty.

The concept of Hunter (1990) about commitment is associated with covenant. If it is compared with students' commitment, the covenant may be defined as being strong or determined to make their expectations come true. The covenant in students context is more self oriented. The students self commitment and covenant are shown by studying hard that broaden their knowledge and prepare themselves for serving and becoming the perspective priests. In other words, becoming priests is a manifestation of their commitment of their calling.

Hunter and Chandler (2005) define calling as work which is a goal of a person's life. The idea is that psychologically, satisfaction and success in working tends to be more than work, but a calling. So, the students' calling to study at the Faculty of Theology shows their strong commitment to become priests by working hard and behave properly as a servant who work as a priest. In other words, to become priest is not easy. It needs a strong commitment and attitude morally and ethically in accordance with the prevailing regulations at the Theological Faculty.

The students' commitment to study may not be done well without the support from their family who care for them. in the interview test for entering to study at the Theological Faculty, the students said that they were supported by their parents or their whole family. In general, the Ambonese or the Moluccan people adore a priest as a person's work. In reality, a priest has to give his or her time fully. Sometimes, he or she 
has to pray for people who are sick at home or in the hospital and day or night serve people who are in needs.

Becoming a priests as their aspiration, the theological students have to have a strong commitment to study hard that may take them five to seven years of studying. Intellectually, their grades have to be good without having at least not more than two Ds. They have to obey the prevailing regulations at the Theological Faculty ethically and morally.

There are at least three important things for students to show their strongcommitments to complete their study, they are:

1. Perseverance, that is, a diligent attitude shown by a student in studying. By having perseverance the students are aware oftheir various activities done with their full spirit to make their expectations to become priests come true. They do not easily give up. The obstacles they might face motivate them to study harder. Their perseverance reflects their strong attitude to do meaningful activities continuously. Perseverance is a loyalty to meet a person's goal.

2. Obedience, that is, being aware of themselves and serious willingness to obey the prevailing regulations at the Theological Faculty. The students are expected to obey the regulations strictly as their discipline attitude of students who are prepared for becoming priests. Their obedience is their spiritual commitment to serve as a perspective priest. Without obedience the students might be kicked out of the Theological Faculty.

3. Consistence, that is, the attitude which is not unstable. It is associated with their motivation to enter the Theological Faculty. In other words, their strong will shown at the beginning of their studying has to be consistently shown during their wholestudying to achieve their goals. Consistence is a norm of their commitment to make a choice to serve as a priest. The choice to become a priest has to be in accordance 
between words and deeds. Therefore, during their study their attitude has to be consistent with their character of their life to support their work or ministry as a priest in the future.

The three important things above has a connection with the students' commitment to become a priest. Leaving one of the three points might bring them far away from aspiration to become a priest. Finishing their study on time and becoming a priest expected by congregations are not easy. They also need support from their whole family who really care for them. The strong caring for the students from their whole family is known as a kalesangculture which will be described below.

\section{Kalesang Values of Parents Who Support For Their Children's Success in Their Studying to Have Their Aspirations}

Kalesang is a traditional expression of the family or parents who show serious continuous caring for their children in various ways.In patriarchal cultures, fathers are responsible for taking care of their children who carry on their fathers' names. In reality, however, mothers are also responsible for supporting their children's needs and education. Mothers now days have their own jobs by working as state officers or running their own business.

S. Sohilait describes by citing from K.A. Ralahalu (2012), that the Moluccan women, besides working for the government or running their own business, they have been involved also in various economic fields, informally as "papalele" women who sell vegetables, fish or fruits along the streets or in the traditional markets. "Papalele" women historically have been part of traditional economy among the speed of modern economic development in Ambon city recently. Also, women weaver who weave woven cloth from Tanimbar, Tepa, Kisar etc. and the women gardeners, farmers in the Moluccas who are not doing nothing but they are experts in working and being responsible for working and building up

JICSA Volume 05- Number 01, June 2016 
their family economy. In other words, mothers are very kalesang or caring for supporting or fulfilling their children's demands.

Mothers' kalesangshows the strong values of their loving care for their children in having education for their bright future. Basically, parents, mothers and fathers, are kalesang or very caring for their children's success in having their aspirations.

Parents' Kalesang for their children' study at the Theological Faculty are really shown in their willingness to support their children to serve God as priests. Abineno, (1982), as a priest, describes that as a servant is sent by God. A priest has to serve with the authority from Jesus Christ not under their own authority. The parents are willing to kalesangor earnestly take care of their children to study at the theological Faculty to be prepared for becoming priests by supporting continuously in material, finance, prayers, and spirituality for their success in studying. Instead of chasing pride, the parents are humbly giving their life to God Who call their children to become a servant of God.

Realizing that having children who serve God, parents are also challenged by the risks of being liked or disliked by their church members. However, their commitment has to be kept strongly with the support from their parents or the whole family in serving God, spreading God's Word and doing His will. So, their parents' kalesang is done in material or prayers not only during their children study but until the end of their life.

Before Christianity enters Ambon, Ambonese and the Moluccan people used to recognize and believe in asuper power that transcends human power which is known as UpuLanite (the Ruler of heaven), and Upu Ume (the Ruler of earth). Cooley describes that theMoluccan people are as a community of the living and the death. The people who are still alive are united with the departed souls of the ancestors in order to preserve their custom. They believe that if they fulfill 


\section{ClaartjePattinama}

the custom they will be a successful person, but if they break the custom they will be heading disaster (Cooley, 1987). In fact, the ancestors are not indicated as God but they are honored as predecessors who establish the customs for the sake of the next generation.

When Christianity enters, Ambonese and the Moluccan people place God as the first position and ancestors are the secondplace. They believe in God, as their Creator, Ruler of heaven and earth. Their ancestors are honored as theirpredecessors who bear the next generations. Therefore, they transmit their calling as priests to the next generation that they will make the right decision to serve God and be blessed in the Moluccas or outside the Moluccas.

As the next generation, they will keep the covenant and expectations of their ancestors or parents to serve God as priests. By continuing to become priests, they will keepcarrying on their family's good names and loyalty, praising and glorifying God in words and deeds daily.

Besides spreading the Word of God and doing teaching ministry, priests also involve in helping their church members solving their problems by doing pastoral ministry that they will be led to manage their own problems. The church members will be brought to be peace makers among themselves and others. If they are in dispute, they will be led to learn how to forgive each other sincerely. The students have to be really prepared for engaging in the various contexts of problems by having lectures and putting them into practice in order to become priests in the future.

Therefore, the students have to strive earnestly for becoming priests by having strong commitments as stated earlier. Their motivations and commitments are along with their parents' caring for their success in being vicars and then ordained as priests. Kalesang is a manifestation of their parents' responsibility for their children education until becoming priests. There is then a cooperation between parents and 
children. On one hand, children strive to put their parents' expectation and covenant into realization, and on the other hand, the parents put their responsibility into realization by having the kalesang culture to fulfill all demands of their children's education.

\section{Conclusion}

The kalesang culture of Ambonese and the Moluccan people may alsobe found in other tribes in Indonesia by taking care of their children earnestly to achieve their aspirations of becoming priests that concern other people. Priests, as spiritual leaders, are seen in their characteristics daily that become a good example for their followers. It's not an easy work. It needsself concept as the chosen sent by God to serve people based on God's will not their own will. Therefore, the culture of selfkalesang and parents' kalesang really contribute to put their aspirations into realization to serve God as priests.

Self kalesang is shown by their loyalty, obedience, and consistence in studying and behaving well as perspective priests that need parents' kalesangor caring for their studying to achieve their aspirations. Cultures, then, may not be separated from human struggling for life in their culture. Achieving their aspirations deals with how they apply the values of their cultures to their striving for life now and in the future.

\section{BIBLIOGRAPHY}

ATESEA (2000), Association For Theological Education in South East Asia Handbook. Manila:

Troika Press.

Abineno, J.L. Ch. (1982), Pedoman Praktis Dalam Percakapan

Pastoral. Jakarta: BPK Gunung Mulia. 


\section{ClaartjePattinama}

Buzan, T. (2001), The Power of Spiritual Inteligence. London: Harper Collins Publisher.

Cote \& Levin (1997), "Student Motivation, Learning

Environment, and Human Capital Acquisition; Toward An Integrated Paradigm of Student Development." Journal of College Student Developmet.Vol. 38 (3).

Cooley, Frank L. (1987), Mimbar danTabta(Hubungan Lembagalembaga Keagamaan dan

Pemerintahan di Maluku Tengah. Jakarta: Pustaka Sinar Harapan.

Duyverman (1927), KortVerslag Van de STOVIL te Ambon.

Hall, B.P. (1992), Panggilan Pelayanan (AlihBahasa). Penerbit Kanisius dan BPK.Judul Asli, Shepherd and Lovers, A Guide to Spiritual Leadership and Christianity Ministry.

Hall, D.T. \& Chandler, E. (2005), "Psychological Success: When the Career Is A Calling." Journal Of Organizational Behavior. Vol. 26.

Hunter, R.J. (Editor) (1990), Dictionary of Pastoral Care and Counseling. Michigan: Abingdon Press.

HendrikRirimase, M. (1989), "Spiritual Formation In Theological Seminary UKIM Ambon.

Dalam S. Amirthandan Yeo. Ch.L. (Editors). Spiritual Formation In Asian Theological

Education.Singapore: The Association For Theological Education In South East Asia. 
The Kalesang Values Contribution to the students..

Marcia, J.E. \& Archer, S. L. (1993), Ego Identity: A Handbook For Psychosocial Research.

New York: Springer Verley.

Ralahalu, K.A. (2012), BerlayarDalamOmbak, Berkarya Bagi

Negeri. Pemikiran Anak Negeri

Untuk Maluku. Ambon: Ralahalu Institut.

Schunk, D.H., Cs. (2008), Motivation In Education: Theory,

Research, And Applications. Third

Edition. New Jersey: Pearson Merril Prentice Hall.

$* * *$

JICSA Volume 05- Number 01, June 2016 